\title{
INTEGRATED WATER QUALITY ASSESMENT FOR THE ANIMAL WATERING IN VELYKOSNYTINSKE EDUCATION AND RESEARCH FARM OF NATIONAL UNIVERSITY OF LIFE AND ENVIRONMENTAL SCIENCES OF UKRAINE
}

L. V. Voitenko, PhD in Chemistry

V. A. Kopilevych, SCD in Chemistry

National University of Life and Environmental Sciences of Ukraine

The assessment of the results of water quality analyses of sources on the territory of NULES research farm in the form of Harrington generalized desirability function was done. The suitability of water intended for use as drinking water by animals was examined using drinking water US EPA regulations and Ukrainian standards. It was shown that water quality is unstable, but good in general. The most problematic parameters are total hardness, nitrate pollution and high Cadmium and Lead content.

Introduction. Agriculture is by far one of the main consumers of the Earth's fresh water. According to expert assessment, 70\% of water withdrawals from watercourses and groundwater are for agricultural usage, three times more than 50 years ago [1]. By 2050 , the global water demand of agriculture is estimated to increase by a further $19 \%$.

Water is an important but poorly studied element of livestock and poultry production. It is estimated [2] that livestock industries consume $8 \%$ of the global water supply, with most of that water being used for intensive, feed-based production. Water using for livestock and poultry production should be considered an essential component of agricultural water resource management, taking into account the type of production system (e.g. grain-fed or mixed croplivestock) and scale (intensive or extensive), the species and breeds of livestock, types of water supply sources, social factors etc.
A lot of chemicals, or their degradation products, present in water used for livestock may occasionally be transmitted to humans in links of the biogeochemical chain soil forming rocks - water - animal food humans [3]. For example, the presence of cadmium $\mathrm{Cd}$ in the aquatic environment and in livestock drinking water is of concern because it bioaccumulates. The biological half-life of cadmium is approximately 200 days. It can persist in animal tissue longer than antagonistic trace metals (Zinc, Copper), causing delayed toxicity. The rate of Cd absorption is higher when ingested through water as compared to dietary intake. Cadmium is retained in the liver and kidney (near $75 \%$ ), but may also be found in muscle tissue and milk [4].

International and Ukrainian water quality guidelines for livestock and poultry watering. Usually it is considered that livestock and poultry need water of similar quality or 
better even to that required by humans [5]. However, like water intake requirements for livestock, water quality requirements are poorly researched and usually defined by acceptability and their effects on livestock performance. Water quality is defined by the series of parameters such as physical properties (temperature, turbidity, electrical conductivity), organoleptic ones (e.g., taste, smell, coloring), physiochemical ones (e.g., salinity, hardness), presence of toxic substances (e.g. heavy metals), microbiological pollution etc. Really the most of farmers consider the microbial aspects of water quality from viewpoint of epidemiological safety of animal production.

Water quality standards for animals are not the same nor are they enforced with the same authority as are those for humans. Water quality recommendations for animals have been made by several foreign and international organizations, such as the US EPA (1973), US National Academy of Sciences (NAS) (1974), Canada (1999 with updates) [6]. The US EPA published proposed water quality standards for irrigation, livestock, aquatic life, wildlife, public freshwater, marine aquatic life and recreational water in 1973 . The criteria were formulated and published by the US EPA pursuant to the Federal Water Pollution Control Act Amendments of 1972 and the Water Quality Act of 1965. The National Academy of Sciences (NAS) report summarizes what was known at the time of publication about effects of nutrient and toxic substances that were found in water consumed by domestic animals. It also contains information about water requirements and the percentages of recommended intake of various chemicals provided by normal daily water consumption, and toxic concentrations for various species.

There is no special European regulation of water quality for livestock watering. Council Directive 2002/32/EC [7] determines, that the same rules concerning the quality and safety of products intended for animal feed have to apply to the quality and safety of water consumed by the animals.
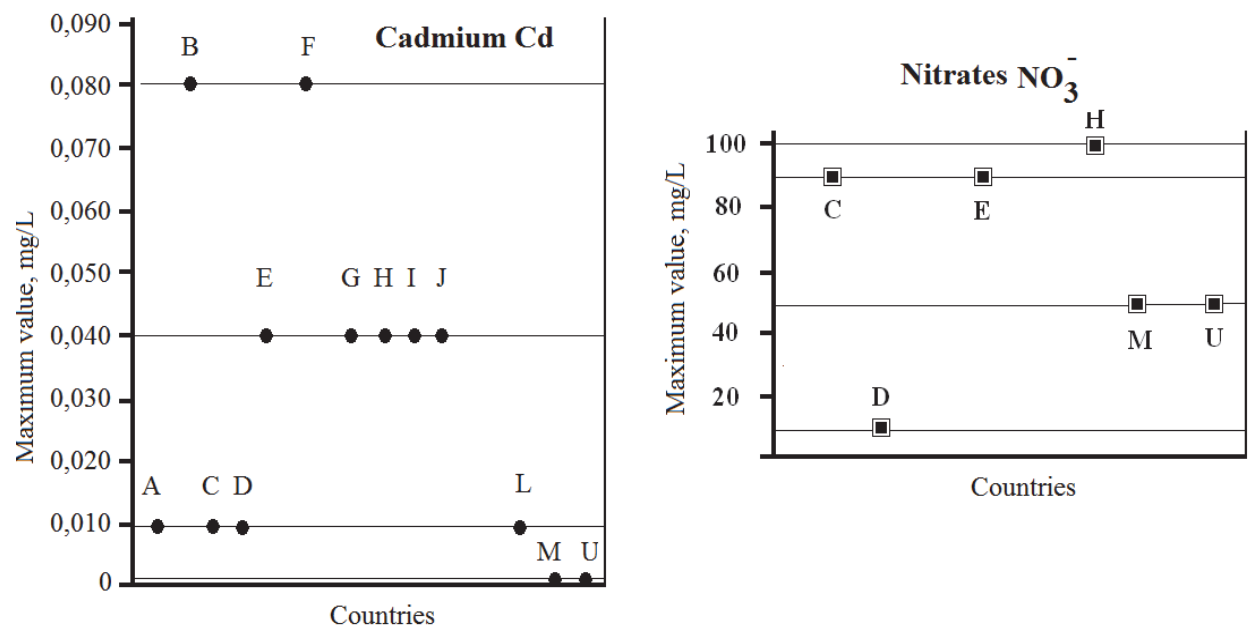

Fig. 1. Comparison of the $\mathrm{MCL}$ (maximum contaminant level) Cadmium $\mathrm{Cd}$ and Nitrates $\mathrm{NO}_{3}{ }^{-}$ concentrations for animals watering in the different regulations: $A$ - South Africa; $B$ - Argentina; C - Australia/New Zealand; D - Brasil 1; E - Brasil 2; F - Canada; G - USA, Colorado state; H Equador; I - FAO; J - USA, New Mexico state; L - Peru; M - Venezuela; U - Ukraine 
The issue of water to be considered as feedingstuffs needs to be examined in the framework of Directive 96/25/EC of 29 April 1996. It should be noted that this definition introduces a number of uncertainties. It should be noted that this formulation introduces a number of uncertainties. How, for example, is to link the amount of water consumed and weight of the feedingstuffs? When making comparison it is necessary to include in recalculation formulas a lot of factors (dry matter intake, breed, type of birth, sex, parity, disease, management system, season conditions etc.) [5].

It was found the maximum allowable value for livestock watering in South Africa, Argentina, Australia/New Zealand, Canada, Chile, Ecuador, Peru and Venezuela and the U.S. states of Colorado and New Mexico. We also used the maximum concentrations suggested by the International Food and Agriculture Organization (FAO) [8].

Ukrainian state regulation in the field of water quality describes requirements to the drinking water for human consumption mainly [9]. In practice the veterinarians use these criteria [10]. A sanitary guideline for animal watering is presented as temporary regalements such as SOU 41.00-37-422:2006 (Standard of Ukrainian organizations) Surface and underground waters: Recommendations for using in livestock and poultry farming [11].

Methodology of the integrated water quality assessment. As previously shown [12] water quality assessment for different kinds of water consumption with using of standardized scale-Harrington's desirability function - is a useful and objective concept perspective for integral estimation. For the calculation of Harrington's desirability partial and generalized functions in multiple water quality parameters we need to determine the score ranges for every tested constituents. In presented research we used two approaches - developed by NAS [13] and Ukrainian regalements [12] (table 1).

Material and methods. A long-term seasonal monitoring (2008-2011) has covered 24 private and public wells (4-15 m deep) used of household farms for animal and poultry watering and 3 sampling points of potable water, used in Research farm of NULES for human and animal watering (fig. 2). This monitoring is part of the State project "Water resources for Ukrainian agrarian areas - state and perspectives" (State registration number 0107U004375). Water quality of those water sources have been analyzed on main parameters including lead, cadmium, copper, zinc, nitrates, dry residue (TDS), total hardness. The water constituents were measured in the Measuring laboratory of surface, underground waters and wastes of Analytical and Bio-inorganic Chemistry \& Water Quality Department, which is the structural subdivision of Ukrainian Laboratory of Quality and Safety of AIS Products of National University of Life and Environmental Sciences of Ukraine (certificate of approval No TÜB Lab-01). Monitoring design was made due to the EPA recommendations [15].

Experimental and discussion. Monitoring wells are constructed to observe conditions at required location. Monitoring well locations are selected on the basis of known or expected hydrologic, geologic, and water quality conditions and the location of pollutant or contaminant sources. Monitoring wells frequently need to be located close to or within areas of pollution or contamination. The animal farm "Velykosnitynske" of National University of Life and Environmental Sciences of Ukraine is such potential source of groundwater pollution.

A total of 105 water samples were collected from 24 different water sources during two seasons over a period of two years (June 19, 2007 and February 02, 2008) and March 12, 


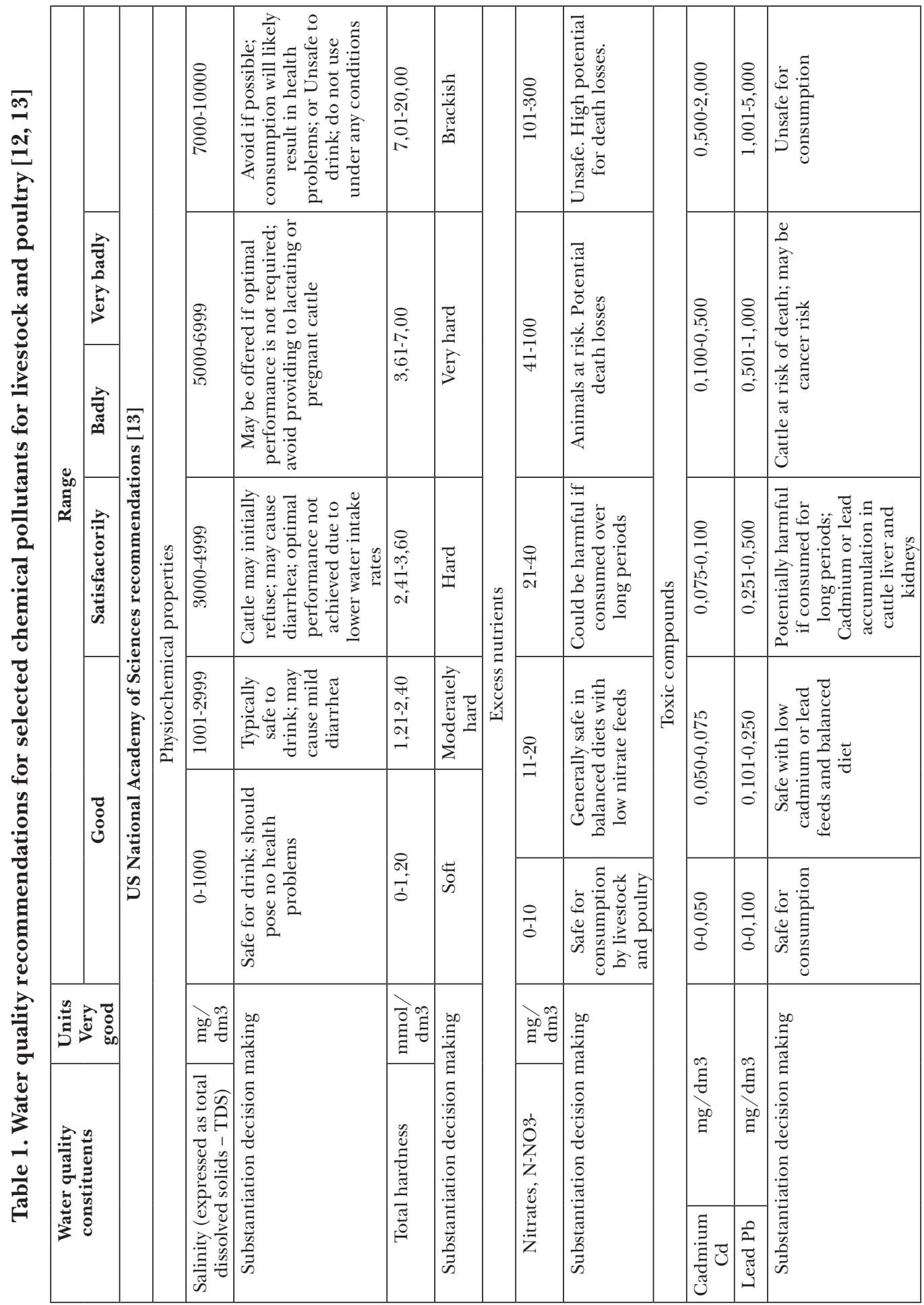






\begin{tabular}{|c|c|c|c|c|c|c|c|c|c|c|c|c|c|c|}
\hline $\begin{array}{l}8 \\
8 \\
0 \\
0 \\
0 \\
0 \\
0 \\
0 \\
0 \\
0\end{array}$ & 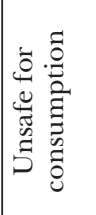 & 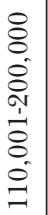 & 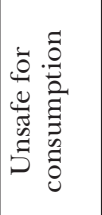 & & & $\begin{array}{l}8 \\
\vdots \\
\vdots \\
0 \\
\vdots \\
\vdots \\
\vdots \\
0\end{array}$ & $\begin{array}{l}8 \\
0 \\
0 \\
1 \\
0 \\
0 \\
0 \\
0\end{array}$ & & $\begin{array}{l}8 \\
\stackrel{8}{0} \\
\stackrel{1}{+} \\
\stackrel{0}{\sim}\end{array}$ & & $\begin{array}{l}8 \\
8 \\
0 \\
\text { ì } \\
\dot{0} \\
\text { v } \\
0\end{array}$ & \begin{tabular}{|c|}
0 \\
8 \\
0 \\
10 \\
0 \\
0 \\
-1
\end{tabular} & $\begin{array}{l}8 \\
0 \\
0 \\
11 \\
8 \\
0 \\
10\end{array}$ & \begin{tabular}{|c}
0 \\
0 \\
0 \\
0 \\
0 \\
$\dot{1}$ \\
$\dot{0}$ \\
0 \\
$\dot{8}$ \\
$\dot{v}$
\end{tabular} \\
\hline $\begin{array}{l}8 \\
8 \\
0 \\
0 \\
1 \\
\\
0 \\
0\end{array}$ & 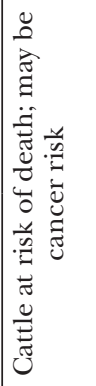 & $\begin{array}{l}8 \\
8 \\
0 \\
\vdots \\
\vdots \\
\dot{1} \\
0 \\
0 \\
\infty\end{array}$ & 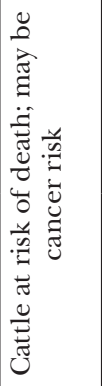 & & & 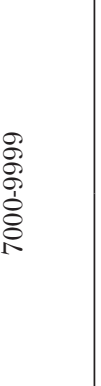 & $\begin{array}{l}8 \\
0 \\
0 \\
1 \\
0 \\
0 \\
10 \\
0\end{array}$ & & $\begin{array}{l}\stackrel{8}{0} \\
\stackrel{1}{\prime} \\
\dot{+}\end{array}$ & & $\begin{array}{l}8 \\
0 \\
\text { - } \\
0 \\
1 \\
10 \\
0 \\
0\end{array}$ & $\mid$\begin{tabular}{c|}
0 \\
0 \\
-1 \\
$\dot{1}$ \\
0 \\
0 \\
0 \\
0
\end{tabular} & $\begin{array}{l}8 \\
8 \\
0 \\
10 \\
0 \\
0 \\
0 \\
0\end{array}$ & $\begin{array}{l}0 \\
0 \\
0 \\
0 \\
0 \\
1 \\
\dot{0} \\
0 \\
0 \\
0\end{array}$ \\
\hline$\frac{2}{2}$ & 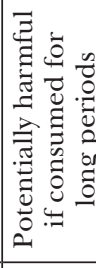 & $\begin{array}{l}8 \\
8 \\
0 \\
8 \\
0 \\
1 \\
8 \\
0 \\
0 \\
0\end{array}$ & 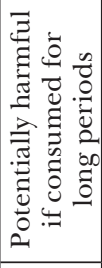 & 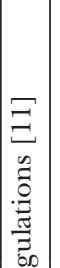 &  & $\begin{array}{l}8 \\
8 \\
\text { d } \\
0 \\
\vdots \\
\vdots \\
\vdots\end{array}$ & $\mid \begin{array}{c}8 \\
010 \\
10 \\
0 \\
0 \\
0\end{array}$ & 莞 & $\frac{\text { Pr }}{\frac{1}{N}}$ & 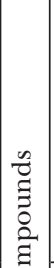 & $\begin{array}{l}0 \\
20 \\
0 \\
0 \\
11 \\
0 \\
0\end{array}$ & $\mid$\begin{tabular}{c|}
0 \\
0 \\
0 \\
1 \\
10 \\
0 \\
0 \\
0
\end{tabular} & $\begin{array}{l}8 \\
8 \\
10 \\
0 \\
1 \\
0 \\
0 \\
0\end{array}$ & $\begin{array}{l}8 \\
0 \\
0 \\
\vdots \\
\vdots \\
8 \\
0 \\
20\end{array}$ \\
\hline 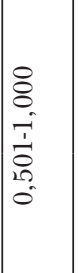 & 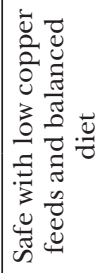 & $\begin{array}{l}8 \\
8 \\
0 \\
+1 \\
\dot{1} \\
\dot{8} \\
\dot{8} \\
\text { v }\end{array}$ & 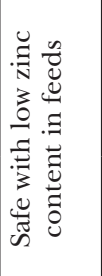 & 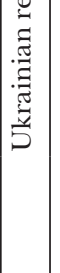 & 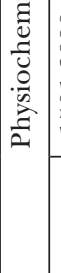 &  & $\begin{array}{l}8 \\
0 \\
0 \\
1 \\
\dot{1} \\
0 \\
10\end{array}$ & 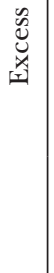 & $\begin{array}{l}\text { શิ } \\
\stackrel{్}{二}\end{array}$ & 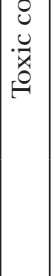 & $\begin{array}{l}0 \\
0 \\
0 \\
\dot{1} \\
\text { ปे } \\
0 \\
0\end{array}$ & $\mid \begin{array}{c}0 \\
1 \\
0 \\
0 \\
1 \\
0 \\
0 \\
0 \\
0\end{array}$ & $\begin{array}{l}8 \\
0 \\
0 \\
\frac{1}{10} \\
0 \\
0\end{array}$ & $\begin{array}{c}8 \\
0 \\
0 \\
10 \\
10 \\
0 \\
0 \\
0\end{array}$ \\
\hline de & 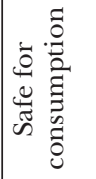 & $\begin{array}{l}8 \\
0 \\
0 \\
\text { ஸे } \\
\text { d. }\end{array}$ & 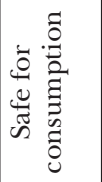 & & & & $\begin{array}{l}0 \\
\hat{1} \\
\hat{o}\end{array}$ & & $\stackrel{0}{\circ}$ & & $\begin{array}{l}\overline{8} \\
8 \\
0 \\
0\end{array}$ & $\left|\begin{array}{l}0 \\
0 \\
0 \\
0 \\
0\end{array}\right|$ & $\begin{array}{l}0 \\
20 \\
0 \\
0 \\
0 \\
0\end{array}$ & $\begin{array}{l}8 \\
0 \\
\vdots \\
0 \\
0 \\
0\end{array}$ \\
\hline 0 & 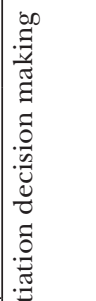 & 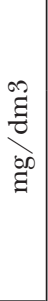 & 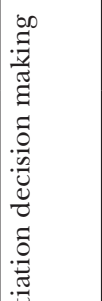 & & & 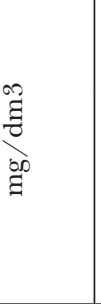 & 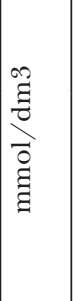 & & 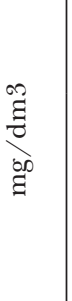 & & $\begin{array}{l}\text { ? } \\
\text { है } \\
\text { के } \\
\text { है }\end{array}$ & $\begin{array}{c}\infty \\
\vdots \\
0 \\
0 \\
0 \\
\vdots\end{array}$ & 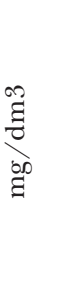 & 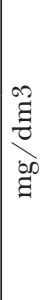 \\
\hline 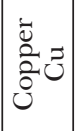 & 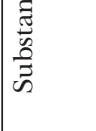 & 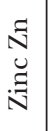 & 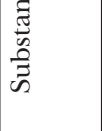 & & & 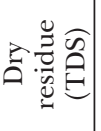 & 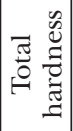 & & 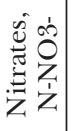 & & 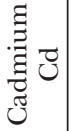 & 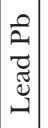 & 它 & 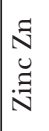 \\
\hline
\end{tabular}




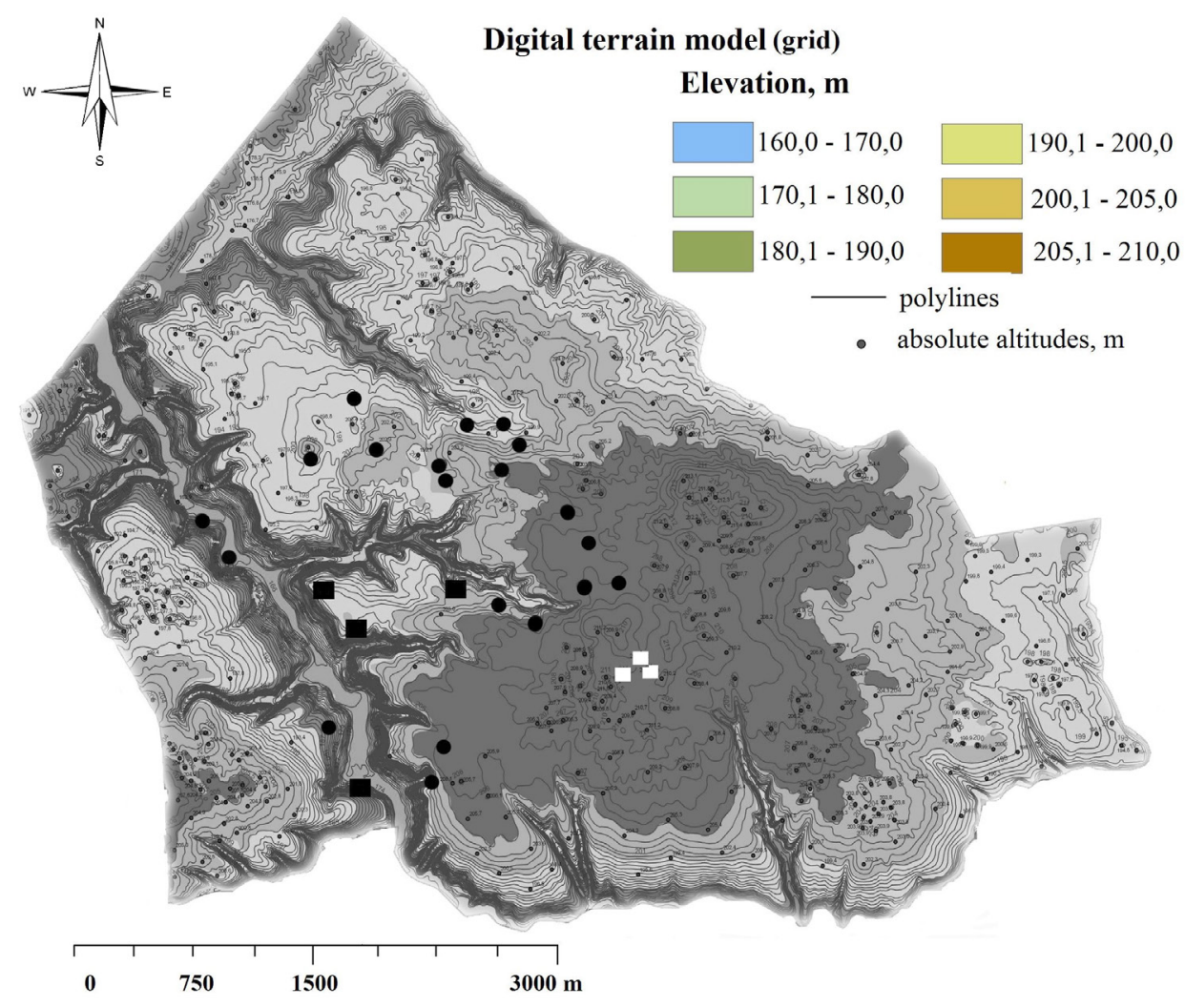

Fig. 2. Mapping [14] of Research station of NULES experimental territory (sampling points wells: • 2007-2008 years; 2011 year; $\square$ - potable water points, 2007-2008 years)

2011. The samples were taken in plastic jerry canes and brought to the laboratory with necessary precautions, all samples were labeled properly. Water samples were analyzed by standard methods [16]. The samples were analyzed for following physicochemical parameters: total dissolved solids (salinity) $(\mathrm{mg} / \mathrm{L})$, total hardness $(\mathrm{mmol} / \mathrm{L})$, nutrients - nitrates content, N-NO3 $(\mathrm{mg} / \mathrm{L})$, and four heavy metals content - Cadmium Cd, Lead Pb, Copper $\mathrm{Cu}$, and Zinc Zn $(\mathrm{mg} / \mathrm{L})$.

These seven parameters were taken for calculation of partial and generalized Harrington desirability function [17] as a water quality assessment index due to developed conception [12]. It is an established fact that the more harmful pollutant is, the smaller is its standard permissible value recommended for drinking water. Therefore, the "weights" for various water quality characteristics are different. Our concept of correct interpretation is based on the objective scale - Harrington desirability function. Essentially, the approach is to translate the functions to a common scale $[0,1]$, combine them using the geometric mean and multicriteria optimization. This scale permits to transform any physical parameter in dimensionless entity expressed in psychophysical terms - "very good", "good", "satisfactorily", "badly", and "very badly". Comparison of principle desirability function calculation as well as its scale, and graphic curves is shown that its methodology 


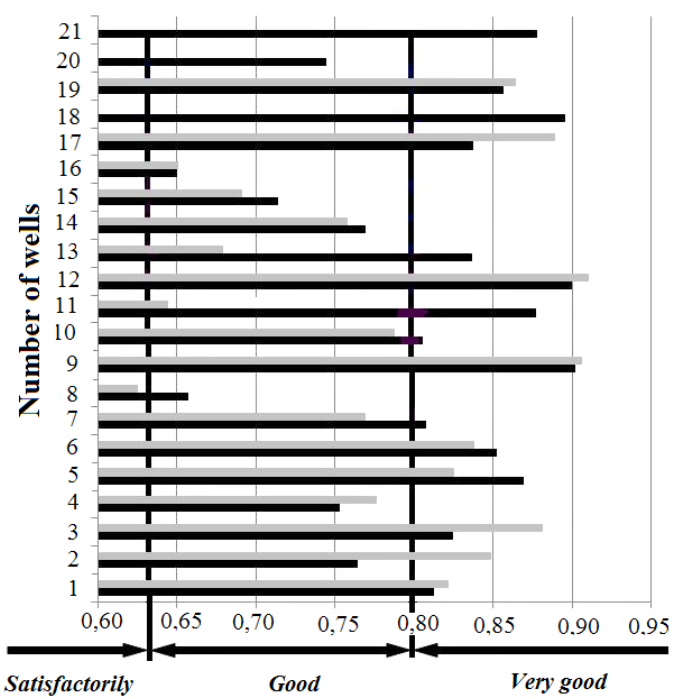

Harrington desirability generalized function $D$ $\square$ Summer season $\quad$ Winter season

Fig. 3. Water quality assessment for animal watering as a Harrington desirability generalized function of 21 wells (2007 and 2008 years data)

is very similar to WQI assessment [18] and dairy cattle drinking water quality index (DCWQI) [19]. It differs only grading scale for absolute values.

Analysis of obtained data was shown (fig.3) that $48 \%$ of samples may be identified as a very good, $48 \%$ - good in general, and $4 \%-$ satisfactorily. But water quality is not stable, that means that water sources are not guarantee completely. The widest variability of desirability function D was observed for well \# 13 - from 0,8368 in summer till 0,6795 in winter season. The worst water quality was fixed in well \# 8 0,6253 in summer season. The worst parameter for this object is the nitrate content, its partial desirability function D (N-NO3) $=0,3120$. Simultaneously water of this well is very hard (D $($ total hardness $)=0,3004)$.

The maximum permitted values of the chemicals varies among the different regulations studied for some substances, although almost being a consensus for others (table 1). In Ukraine the limit values for animal watering seem to be based on quality criteria established for human health (drinking water). USA regulations are softer in a few positions (heavy metals) but harder in other ones (for example, total hardness). For the comparing of the requirements it was calculated partial and generalized desirability function D for two wells according to US and Ukrainian regulations (table 2). It seems that the strongest deviations of partial desirability function $\mathrm{D}$ are observed for the parameters of total hardness, and Cadmium $\mathrm{Cd}$ and Lead $\mathrm{Pb}$ content. Ukrainian regulations permit to use for animal watering water having total hardness $7 \mathrm{mmol} / \mathrm{L}$, when NAS criteria classify it as very hard, practically brackish. Deviations of integrated assessment according to US and Ukraininan regulations are very significant and achieved $85-88 \%$ (table 2). Analysis of the partial desirability function $\mathrm{D}$ indicates that the greatest variations observe in the criteria of total hardness - US limit is much stricter; and Cadminum and Lead contents - US limit is much softer (these data noted as grey background on the table columns) (fig.4).

Three years later (2011) it was carried the second tour of water sampling. Three water samples presents the wells sources (\# 1-3



Fig. 4. Water quality assessment for animal watering as a Harrington desirability generalized function of three wells, and three samples of tap water (2011) 


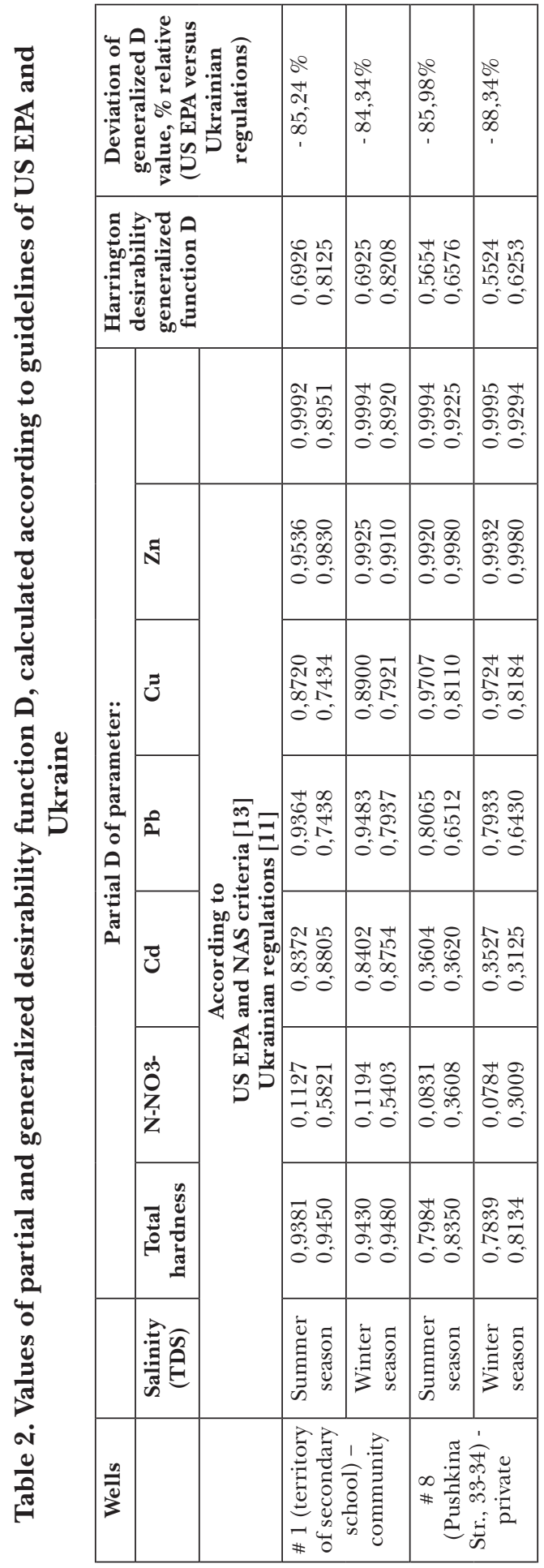

coresponded to the first tour) and three samples of tap water presents centralized water supply.

Analysis of obtained data (fig. 4) shows that in general underground and tap waters may be estimated as "very good" or "good" qualities. The lowest values of partial D, dicreased integrated assessment of underground water, are nitrate content (well \#2 - 0,7208), total hardness (well \# 3 0,5082 ), cadmium and zinc content (well \# 2 - 0,5924 and 0,7920 correspondently).

Tap water is characterized of more stable quality. But integrated assessment of potable water of central supply was reduced due to the detection of Cadmium and Lead high content. It seems that the most likely cause of this phenomenon is that for the repair of worn-out water supply communications are used filling composits containing these heavy metals.

\section{Conclusions}

So, during the study it was observed that the water quality of local sources on the territory of Velykosnytinske Education and Research farm of National University of Life and Environmental Sciences of Ukraine is good or satisfactory for animal watering. But integrated assessment as a Harrington desirability function $\mathrm{D}$ shows that water quality is not stable in space-time scale. Anthropogenic contamination is observed in particular in the form of nitrate pollution. But biogeochemical factor such as continuous contact of carbonated soils with underground waters influences on water quality too. It is observed as high water total hardness and salinity. Tap water contains high Cadmium and Lead content. It is important to stress that water assessment for animal watering depends on used regulations. In particular, US and Ukrainian water requirements for livestock are significantly different in the evaluation of the total hardness, content of heavy metals. This substantially shows the obtained results. 


\section{References}

1. The OECD and the PBL Netherlands Environmental Assessment Agency. The OECD Environmental Outlook to 2050. Available at: http://www.oecd.org/environment/indicators-modelling-outlooks /49846090.pdf.

2. Schlink, A.C., Nguyen, M.-L., Viljoen, G.J. (2010). Water requirements for livestock production: a global perspective. Revue scientifique et technique (International Office of Epizootics), 29(3), 603-619. Available at: http:/ / www.oie.int/doc/ged/d9643. pdf.

3. Kovalsky, V.V. (1979). Geochemical ecology and problems of health. Philos Trans. Royal Society London Series B Biol Sci, 288 (1026), 185-191.

4. South African Water Quality Guidelines. (1996). Volume 5: Agricultural Water Use: Livestock Watering. Second Edition. Pretoria: Department of Water Affairs and Forestry, 148. Available at: http://www. iwa-network.org/filemanager-uploads/WQ_Compendium/Database/Future_analysis/081.pdf.

5. Ayers, R.S., Westcot, D.W. (1985). Water quality for agriculture. Rome: Food and Agriculture Organization of the United Nations, 29 (1), 186. Available at: httphttp://www.waterboards.ca. gov/water_issues/programs/tmdl/records/state_board/1985/ref2648.pdf.

6. Gupta, Ramesh C. (2012). Veterinary Toxicology: Basic and Clinical Principles, 2d Edition. Academic Press, 1305-1317.

7. Directive 2002/32/EC of the European Parliament and of the Council of 7 May 2002 on undesirable substances in animal feed. Available at: http:/ / eur-lex.europa.eu/resource.html?uri=cellar:aca28b8c-bf9d-444fb47268f71df28fb.0004.02/doc_1\& pdf.

8. Valente-Campos, S. Souza Nascimento, E., Arag o Umbuzeiro, G. (2014).Water quality criteria for livestock watering - a comparison among different regulations. Acta Scientiarum. Animal Sciences, 36 (1), 1-10. Available at: http:/ / www.scielo.br/pdf/asas/v36n1/v36n1a01.pdf.

9. Ukrainian State Sanitary Standards and Rules 2.2.4-171-10 Hygienic requirements to drinking water for human consumption. Available at: http:/ / zakon4.rada.gov.ua/laws/show/z0452-10.

10. Sokolyuk,V.M. (2013). The characteristics of water quality for animals watering in Nord-Eastern biogeochemical zone of Ukraine. Posts Sumy National Agrarian University. Series Biology: Veterinary, 1(32),184-187. Available at: http://www.nbuv.gov.ua/old_jrn/Chem_Biol/Vsna/ vet/2013_2/53.pdf.

11. SOU 41.00-37-422:2006 (Standard of Ministry of Agrarian Policy of Ukraine) Surface and underground waters. Adjustments for using in livesctock and poultry farming. Registrated 13.12.2066, No 1272. Kyiv: Publ. Ministry of Agrarian Policy of Ukraine, 24.

12. Voitenko, L.V., Kopilevich, V.A., Strokal, M.I. (2015). The conception of water quality assessment used Harrington's desirability function for different kinds of water consumption. Biological Resources and Nature Management, 7 (1-2), 25-36.

13. Nutrients and toxic substances in water for livestock and poultry. Subcommittee on Nutrient and Toxic elements in water, Commettee on Animal nutrition, Doard on Agriculture and Renewable Resources, Commission on Natural Resources, National Research Council. Wasington D.C. (1974). National Academy Press, 93.

14. Kovalchuk, I.P., Evsyukov. T.O., Mkrtchyan, O.S. (2009). Geospatarial simulating of potential of degradation processes development on arable soils. Zemleustriy i kadastr: Scientific And Production Journal. Kyiv: Urazhai, 4, 72.

15. Hill, M.K. (2010). Understanding environmental pollution. Textbook, 3d Edition. Cambridge: University Press, 238-244.

16. Rice, E.W., Baird R.B., Eaton, A.D., Cleasceri L.S. ed. (2012). Standard methods for the examination of water and wasterwater, 22nd edition. American Public Health Association, American Water Works Association, Water Environment Federation.1496.

17. Pavan, M., Todeschini, R. (2008). Data Handling in Science and Technology. Volume 27: Scientific Data Ranking Methods: Theory and Applications. Elsevier, 66-68.

18. Abbasi, T., Abbasi, S.A. (2012). Water quality indices. Amsterdam: Elsevier Science Ltd, 384.

19. Gharibi, H., Sowlat, M. H., Mahvi, A. H. (2012). Development of a dairy cattle drinking water quality index (DCWQI) based on fuzzy inference systems. Ecological Indicators, 20, 228-237.

20. Lardner, H.A., Braul, L., Schwartzkopf-Genswein, K. (2013). Consumption and drinking behavior of beef cattle offered a choice of several water types. Livestock Science, 157( 2-3), 577-585. 


\section{АНОТАЦІЯ}

Войтенко Л.В., Копілевич В.А. Інтегральна оиінка якості води для напування тварин на території навчально-дослідного господарства «Великоснітинське» Наиіонального університету біоресурсів і природокористування Украӥни // Біоресурси і природокористування. -2016. 8, № 3-4. - C. 43-52.

Проведено очінку результатів аналізів якості води вододжерел, розташованих на території навчального господарства НУБіП Украӥни, у вигляді узагальненої функиї бажаності Харрінгтона. 3 використаннам стандартів Агентства із захисту довкілля США (US EPA) та украӥнсъких нормативів очінено придатність питної води для тварин. Показано, шо якість води $\epsilon$ нестабільною, проте в иілому доброю. Найбільш проблемними показниками виявилися загальна твердість, нітратне забруднення та підвищений вміст кадмію та свинцю.

\section{АННОТАЦИЯ}

Войтенко Л.В., Копилевич В.А. Интегральная оченка качества питвевой водь для животных на территории учебно-опьтного хозяйства «Вэлькоснитынсъкэ» Наиионального университета биоресурсов и природопользования Украины // Биоресурсы и природопользование. 2016. - 8, 3-4. - C. 43-52.

Выполнена оченка результатов анализов качества води источников, расположенных на территории опьтного хозяйства НУБиП Украинъ, в виде обобщённой функиии желательности Харрингтона. С использованием стандартов Агентства по зашите окружающей средъ США (US EPA) и украинских стандартов была оченена пригодность водъ для животных. Показано, что качество водъ является нестабильным, хотя в иелом хорошим. Наиболее проблемными показателями оказались общая жесткость, нитратное загрязнение и повышенное содержание кадмия и свиниа. 